\title{
History in the Making: Establishing an Institutional Archive at The College of The Bahamas
}

\section{Antoinette Seymour The College of The Bahamas ${ }^{1}$}

\begin{abstract}
As the College of The Bahamas transitions to a university, an institutional archive housing records of legal, administrative, financial, educational, cultural, and historical significance has been established. The COB Institutional Archive will collect and preserve records and documents deemed to have permanent value, thereby making them accessible for future researchers. The archive, presently located in the Harry C. Moore Library Special Collections area, will include not only institutional records, manuscripts and documents but also College catalogues and other published ephemera.
\end{abstract}

\section{INTRODUCTION}

An institutional archive houses records of legal, administrative, financial or historical significance (Purcell, 2012, p. 4); in sum, it is the institution's memory.

College and university archives collect records and documents which are deemed to have permanent value and should be preserved and made accessible for future researchers. A college or university archive also houses inactive and unused (in the course of daily business) official records from all units to, foremost, protect them from destruction, and manage their use.

As the College of The Bahamas (COB) has passed its 40th year of operation, the need for an institutional archive has become paramount.

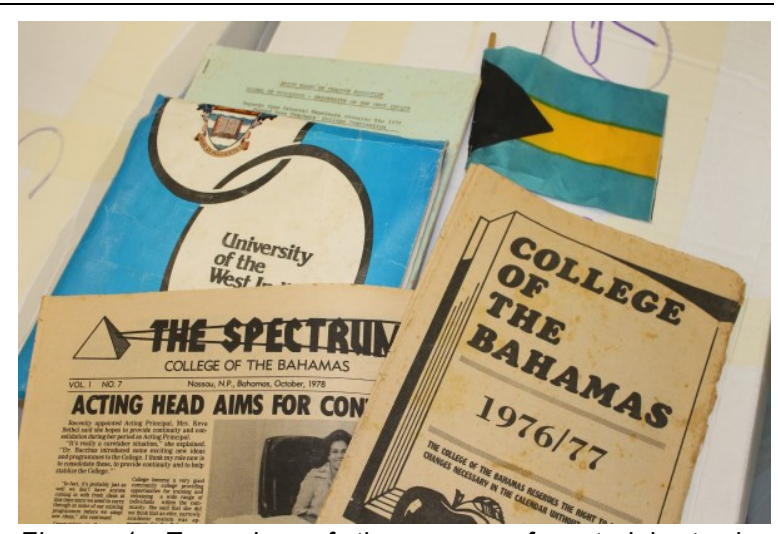

Figure 1. Examples of the range of materials to be collected and preserved: student newspaper, The Spectrum, UWI/COB collaboration document, and the College of The Bahamas catalogue 1976/77. Photograph: Andrew Seymour, Libraries \& Instructional Media Services.

\section{Mission}

The newly-established College of The Bahamas Institutional Archive has the mission to connect people, expertise and archival or historical records in a physical

\footnotetext{
${ }^{1}$ Antoinette Seymour, Archivist, Libraries and Instructional Media Services, The College of The Bahamas, P.O. Box N-4912, Nassau, Bahamas.

Acknowledgments: The author benefitted from a year-long attachment at the University of Glasgow, 2013-2014. E-mail: antoinette.seymour@cob.edu.bs

APA reference: Seymour, A. (2015). History in the making: Establishing an institutional archive at The College of The Bahamas. The International Journal of Bahamian Studies, 21(1), 4-6. http://dx.doi.org/10.15362/ijbs.v21i1.252
} 
and virtual environment that supports research and teaching and nurtures learning. Not only will the COB Institutional Archive be a secure repository for the existing collection of documents, but the archives staff must also actively collect unique, original records relating to the establishment and history of The College, organize and process them, and, finally, make them accessible for research.

Like many college and university archives, the COB Archive was established under the aegis of the College's library. Presently the Archive is attached to the Libraries and Instructional Media Services department. This allows the unit not only to collaborate with library staff and become integrated with library programmes, but also ensures its operational sustainability in terms of staffing, budget and facilities within The College.

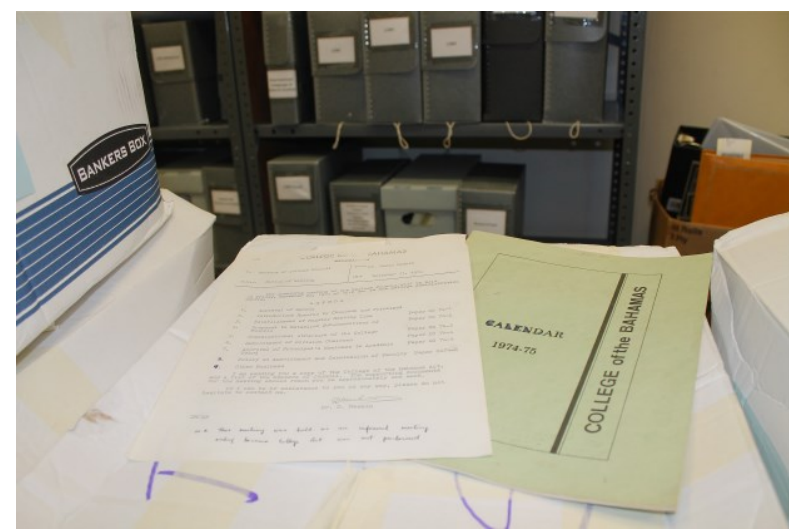

Figure 2. Managing a collection. Photograph: Andrew Seymour, Libraries \& Instructional Media Services.

\section{First Steps}

In the initial stages of setting up the institutional archives, a document holding room and an office were allocated in the Special Collections area of the Harry C. Moore Library and Information Centre. This allows the archival holdings to be housed in a controlled environment. It also permits researchers wishing to consult documents to do so under supervision.
The COB Archive Collections Policy was developed to guide what records and documents will be collected. The policy outlines the procedures for acquiring, arranging, processing, preserving and facilitating physical and electronic access to the records and documents.

First steps include conducting a survey of archival materials held by all departments and units within The College with the view to transferring or acquiring them for the institutional archive. The survey will help guide the growth of the archive, describing the historical range of materials, formats, their physical condition and the approximate sizes of the collections of records. Also included in the initial steps will be an educational outreach or awareness campaign about the role of the institutional archive, the importance of preserving the institution's history and heritage and the need to preserve institutional records as evidence.

The COB archival collection will include all official records and reports, administrative files, minutes, correspondence, speeches, architectural and building plans, maps, student records, College catalogues, course syllabi, student and faculty handbooks, invitations, event programmes, photographs, posters, College memorabilia, and other ephemera that might document the history and development of the institution.

\section{Subsequent Steps}

Once collections are acquired, the massive task of processing them will commence. This will entail organizing the records and documents, sorting and arranging them, removing duplicate or unsuitable material, preserving materials and creating indexes and finding aids.

Making records and documents accessible to students, faculty, staff and the general public for research is also part of the Archive's remit. Outreach programmes will encourage 
the academic community and the public to make use of the documents and records.

\section{Collaboration}

COB Archive works closely with many different units of The College. The Libraries and Instructional Media Services Special Collections department provides space for users to consult and view records in a controlled environment as well as exhibit space (Walker \& Ballance, 2015). Fragile materials or documents that are of high research interest will be digitized and made available through the College's collection on the Digital Library of the Caribbean, thereby preserving them from wear and tear (Wooldridge, Taylor \& Sullivan, 2009). Oral history recordings will be archived or shared with "From Dat Time", the College's Oral and Public History Institute (2013). The Archive will collaborate with departments such as the College Council and President's Office to obtain official College documents. The Office of Communication and Institutional Advancement has already begun assisting with promoting the $\mathrm{COB}$ Institutional Archive within and outside of the institution and will help contact alumni who may wish to donate materials and memorabilia or provide financial support. And, finally, implementing an automated system for accessing archival holdings will entail collaboration with the LIMS Systems Librarian and the Office for Information Technology.

\section{Vision: Toward a purpose-built repository}

The vision for the COB Institutional Archive is that it will eventually be housed in a stateof-the-art structure on the COB campus, as indicated in the College's Master Plan (2014). These premises would be large enough to properly house the collections of institutional records in a controlled space, with special attention paid to temperature, humidity and pest control. It would also have ample space for offices, working areas for organizing and processing materials, preservation, disaster-preparedness and recovery, and finally, adequate public access space for researchers to consult the records.

\section{Conclusion}

The task of organizing the COB Institutional Archive is monumental and will entail the collaboration and support of all College constituents to guarantee its success and sustainability.

\section{REFERENCES}

College of The Bahamas. (2014). Master plan final review. Orlando, FL: HKS Architects. http://www.cob.edu.bs/Council/MasterPlan .pdf

College of The Bahamas. (2013, July 11). PM: Oral and public history institute critical to country's future [press release]. http://www.cob.edu.bs/News/Archive/FDT launch.php

Purcell, A. D. (2012). Academic archives: Managing the next generation of college and university archives, records and special collections. Chicago: NealSchuman.
Walker, B. L., \& Ballance, V. C. (2015). Forty years of development: Library services at the College of The Bahamas. The International Journal of Bahamian Studies, 20(2), 41-47. http://dx.doi.org/10.15362/ijbs.v20i2.232

Wooldridge, B., Taylor, L., \& Sullivan, M. (2009). Managing an open access, multiinstitutional, international digital library: The Digital Library of the Caribbean. Resource Sharing \& Information Networks, 20(1-2), 35-44. http://dx.doi.org/ $10.1080 / 07377790903014534$ 